University of Nebraska - Lincoln

DigitalCommons@University of Nebraska - Lincoln

3-1974

\title{
Lysimetric Calibration of the Bowen Ratio-Energy Balance Method for Evapotranspiration Estimation in the Central Great Plains
}

Blaine L. Blad

Norman J. Rosenberg

Follow this and additional works at: https://digitalcommons.unl.edu/agronomyfacpub

Part of the Agricultural Science Commons, Agriculture Commons, Agronomy and Crop Sciences Commons, Botany Commons, Horticulture Commons, Other Plant Sciences Commons, and the Plant Biology Commons

This Article is brought to you for free and open access by the Agronomy and Horticulture Department at DigitalCommons@University of Nebraska - Lincoln. It has been accepted for inclusion in Agronomy \& Horticulture -Faculty Publications by an authorized administrator of DigitalCommons@University of Nebraska - Lincoln. 


\title{
Lysimetric Calibration of the Bowen Ratio-Energy Balance Method for Evapotranspiration Estimation in the Central Great Plains ${ }^{1}$
}

\author{
Blaine L. Blad and Norman J. Rosenberg \\ Conservation and Survey Division and Dept. of Horticulture and Forestry, University of Nebraska, Lincoln 68503
}

(Manuscript received 25 July 1973, in revised form 27 November 1973)

\begin{abstract}
Most reports show good agreement between evapotranspiration (ET) rates estimated by the Bowen Ratio-Energy Balance (BREB) method and rates measured with lysimeters, although underestimation by the BREB model has occasionally been reported. This study was conducted to evaluate the performance of the BREB technique in the climatic conditions characteristic of the central Great Plains, a region where a significant proportion of the energy consumed by evapotranspiration is supplied from advected sensible heat.

Agreement between the BREB method and lysimetric measurements of ET is good during non-advective periods but during advective periods the BREB model underestimates ET by about $20 \%$. Data collected in this study suggest that the difference is due primarily to an inequality of the exchange coefficients for heat $\left(K_{h}\right)$ and water vapor $\left(K_{w}\right)$. In the development of the BREB method these coefficients are assumed to be identical but our results indicate that the ratio $K_{h} / K_{\text {to }}$ is greater than 1 for the stable conditions associated with the downward transport of sensible heat.
\end{abstract}

\section{Introduction}

Accurate estimates of evapotranspiration (ET) are often required in field studies where lysimeters are unavailable to provide direct measurements. Methods based on micrometeorological data which provide reliable ET estimates must then be applied.

Studies are presently being conducted in the Platte River Valley in east central Nebraska to determine, for input into hydrologic models, characteristic ET rates of the different crops commonly grown in that area. The Bowen Ratio-Energy Balance (BREB) method, because of its simplicity and reliability, is one model being used. This model will also be used as a field standard to calibrate other ET models based on crop resistance and mass transfer. To check its reliability in the climatic regime characteristic of the central Great Plains the BREB method was calibrated against weighing lysimeters located at Mead, Nebr. $\left(41^{\circ} 09^{\prime} \mathrm{N}, 96^{\circ} 30^{\prime} \mathrm{W}\right)$.

In eastern Nebraska from late spring to mid-summer energy consumed by evapotranspiration often exceeds the energy available from net radiation by a significant amount (Rosenberg, 1969). This additional energy is supplied by sensible heat which is "advected" into the area from arid regions which are primarily to the south and west of eastern Nebraska.

1 Published as Paper No. 3651, Journal Series, Nebraska Agricultural Experiment Station. The work reported was conducted under Nebraska Agricultural Experiment Station Project No. 20-31. Presented at 11th AMS Conference on Agricultural Forest Meteorology, 8-10 January 1973, Durham, N. C.
The term "advection," as used in this study, requires definition. Advection has been defined as "The process of transport of an atmospheric property solely by the mass motion of the atmosphere." ${ }^{\prime 2}$ In recent evapotranspiration research a more limited meaning has been applied to the term and advection refers to the transfer of energy in the horizontal plane in the downwind direction.

Terms such as local or border advection and global or large-scale advection have been used to identify the source of the preconditioned air (Slatyer and McIlroy, 1961; Hanks et al., 1971). Slatyer and McIlroy suggest that large-scale or upper level advection may lead to energy consumption by $L E$ which exceeds the average net radiation received. This may arise because of the passage across the evaporating surface of warm dry air masses generated over large, relatively hot dry surfaces elsewhere.

The energy balance at the surface may be determined from

$$
R_{n}=L E+H+S,
$$

where $R_{n}$ is the net radiation, $L E$ the latent heat flux, $H$ the sensible heat flux, and $S$ the soil heat flux. Whenever $L E$ (as measured by the lysimeters) exceeded $R_{n}-S$, then sensible heat was drawn from the air and consumed in evaporation. Although the downward transport of sensible heat can occur without advection,

\footnotetext{
${ }^{2}$ Huschke, R. C., Ed., 1959: Glossary of Meteorology, Boston, Amer. Meteor. Soc., p. 10-11.
} 
and often does during the inversion conditions of late evening and night, the magnitude of $H$ during the daytime inversion conditions encountered here is far in excess of any quantities of sensible heat generated at the crop surface earlier in the day. The consumption of sensible heat by $L E$ was therefore considered to be prima-facie evidence of advection.

Tanner (1960), Pruitt and Lourence (1968) and Denmead and McIlroy (1970) have shown good agreement between lysimeter and BREB estimates of latent heat fluxes $(L E)$ under non-advective conditions. Fritschen (1965a, 1966) calibrated the BREB model against lysimeters and applied it in the field. He found the method to be effective in conditions of strong sensible heat advection. Rosenberg (1969) and Stearns (1970), however, observed that the BREB method underestimated ET.

The primary objective of this study is to examine the performance of the BREB technique under both advective and non-advective conditions and to suggest possible explanations for differences observed between ET rates measured by lysimeters and those calculated by the BREB method.

\section{Experimental methods}

Four studies were conducted during the period from 26 June to 2 August 1970, at the Micrometeorology Research Laboratory located near Mead, Nebr. The experimental field, planted to soybeans, measured $170 \mathrm{~m}$ by $105 \mathrm{~m}$. Fetch at the site of the lysimeters was approximately $100 \mathrm{~m}$ to the south, $70 \mathrm{~m}$ to the north, and at least $45 \mathrm{~m}$ to the east or west. Crop height was approximately $75 \mathrm{~cm}$ at the end of the first study and $100 \mathrm{~cm}$ during the last two studies. The crop was well supplied with water so that potential ET conditions prevailed at all times.

Net radiation $\left(R_{n}\right)$ was measured with two Middleton (Model CN6) miniature net radiometers at an elevation of $180 \mathrm{~cm}$. Soil heat flux $(S)$ was obtained with two Middleton soil heat flux plates buried $5 \mathrm{~cm}$ deep. Air and vapor pressure profiles were measured with thermocouple psychrometer assemblies described by Rosenberg et al. (1972). With this instrument measurements are made at a reference level and at 25, 50 and $100 \mathrm{~cm}$ above it. Accuracy and response of the psychrometer assemblies were checked twice hourly by automatically moving all sensors into the same horizontal plane and, noting the agreement in dry and wet bulb temperatures. Corrections were made during the later computational process.

Two improved van Bavel-Myers automatic weighing lysimeters (Rosenberg and Brown, 1970) were used in this study. These lysimeters have a specified precision of $0.01 \mathrm{~mm}$ and an accuracy of $0.05 \mathrm{~mm}$.

All meteorological measurements were made twice on 15-min cycles. Data were logged on punch tape with an automatic data system. Raw data were converted from the digitized emf record of individual sensors into parametric form by a series of computer programs. Results were plotted with a Cal-Comp plotter (Brown and Rosenberg, 1969).

\section{Calculations}

The BREB equation may be written as

$$
L E=\frac{-\left(R_{n}+S\right)}{1+\left(\frac{C_{p} P}{L \epsilon}\right)\left(\frac{K_{h}}{K_{w}}\right)\left(\frac{\Delta T / \Delta z}{\Delta e / \Delta z}\right)},
$$

where $R_{n}$ is net radiation, $S$ soil heat flux, $C_{p}$ the specific heat of air at constant pressure, $P$ atmospheric pressure, $L$ the latent heat of vaporization, $\epsilon$ the ratio of the molecular weights of water to dry air, $K_{h}$ and $K_{w}$ the transfer coefficients for sensible and latent heat (assumed identical), and $\Delta T$ and $\Delta e$ temperature and

TABLE 1. Error analysis of BREB-calculated $L E$ in four 1970 tests. Data are overall averages of measurements made at the times of maximum, mean and minimum $L E$ on each day during a study period.

\begin{tabular}{|c|c|c|c|c|c|c|c|c|c|c|c|c|c|}
\hline \multirow[b]{2}{*}{ Study } & \multirow[b]{2}{*}{ Dates } & \multirow[b]{2}{*}{$\begin{array}{c}R_{n}+S \\
\left(l_{y}\right. \\
\left.\min ^{-1}\right)\end{array}$} & \multicolumn{4}{|c|}{ Advective conditions } & \multirow[b]{2}{*}{$\begin{array}{c}\text { Relative } \\
\text { error } \\
(\%)\end{array}$} & \multirow[b]{2}{*}{$\begin{array}{c}R_{n}+S \\
(1 \mathrm{y} \\
\left.\min ^{-1}\right)\end{array}$} & \multicolumn{4}{|c|}{ Non-advective conditions } & \multirow[b]{2}{*}{$\begin{array}{c}\text { Relative } \\
\text { error } \\
(\%)\end{array}$} \\
\hline & & & $\begin{array}{c}\Delta T \\
\left({ }^{\circ} \mathrm{C}\right)\end{array}$ & $\begin{array}{c}\Delta e \\
(\mathrm{mb})\end{array}$ & $\begin{array}{c}L E \\
(1 \mathrm{y} \\
\left.\min ^{-1}\right)\end{array}$ & $\begin{array}{c}\sigma L E \\
(1 \mathrm{y} \\
\left.\min ^{-1}\right)\end{array}$ & & & $\begin{array}{c}\Delta T \\
\left({ }^{\circ} \mathrm{C}\right)\end{array}$ & $\begin{array}{c}\Delta e \\
(\mathrm{mb})\end{array}$ & $\begin{array}{c}\text { (ly } \\
\left.\min ^{-1}\right)\end{array}$ & $\begin{array}{c}\sigma L E \\
(\mathrm{ly} \\
\left.\min ^{-1}\right)\end{array}$ & \\
\hline $70 / 2$ & $\begin{array}{l}26 \text { June-- } \\
6 \text { July }\end{array}$ & $\begin{array}{l}0.80 \\
0.46 \\
0.13\end{array}$ & $\begin{array}{l}0.12 \\
0.12 \\
0.12\end{array}$ & $\begin{array}{l}-0.51 \\
-0.36 \\
-0.20\end{array}$ & $\begin{array}{l}0.96 \\
0.58 \\
0.19\end{array}$ & $\begin{array}{l}0.09 \\
0.08 \\
0.10\end{array}$ & $\begin{array}{r}9 \\
13 \\
54\end{array}$ & $\begin{array}{l}0.82 \\
0.52 \\
0.21\end{array}$ & $\begin{array}{l}-0.09 \\
-0.08 \\
-0.08\end{array}$ & $\begin{array}{l}-0.48 \\
-0.35 \\
-0.23\end{array}$ & $\begin{array}{l}0.64 \\
0.41 \\
0.17\end{array}$ & $\begin{array}{l}0.06 \\
0.04 \\
0.03\end{array}$ & $\begin{array}{r}9 \\
10 \\
17\end{array}$ \\
\hline $70 / 3$ & $6-10 \mathrm{July}$ & $\begin{array}{l}0.88 \\
0.53 \\
0.17\end{array}$ & $\begin{array}{l}0.07 \\
0.07 \\
0.07\end{array}$ & $\begin{array}{l}-0.60 \\
-0.38 \\
-0.16\end{array}$ & $\begin{array}{l}0.93 \\
0.64 \\
0.24\end{array}$ & $\begin{array}{l}0.07 \\
0.07 \\
0.12\end{array}$ & $\begin{array}{r}8 \\
11 \\
50\end{array}$ & $\begin{array}{l}1.00 \\
0.54 \\
0.09\end{array}$ & $\begin{array}{l}-0.03 \\
-0.10 \\
-0.16\end{array}$ & $\begin{array}{l}-0.84 \\
-0.56 \\
-0.28\end{array}$ & $\begin{array}{l}0.95 \\
0.51 \\
0.07\end{array}$ & $\begin{array}{l}0.06 \\
0.04 \\
0.02\end{array}$ & $\begin{array}{r}6 \\
8 \\
28\end{array}$ \\
\hline $70 / 4$ & 14-22 July & $\begin{array}{l}0.73 \\
0.42 \\
0.10\end{array}$ & $\begin{array}{l}0.25 \\
0.21 \\
0.17\end{array}$ & $\begin{array}{l}-0.53 \\
-0.41 \\
-0.29\end{array}$ & $\begin{array}{l}1.00 \\
0.59 \\
0.18\end{array}$ & $\begin{array}{l}0.14 \\
0.11 \\
0.06\end{array}$ & $\begin{array}{l}14 \\
18 \\
33\end{array}$ & $\begin{array}{l}0.90 \\
0.56 \\
0.22\end{array}$ & $\begin{array}{l}-0.04 \\
-0.06 \\
-0.09\end{array}$ & $\begin{array}{l}-0.47 \\
-0.40 \\
-0.34\end{array}$ & $\begin{array}{l}0.83 \\
0.50 \\
0.17\end{array}$ & $\begin{array}{l}0.07 \\
0.05 \\
0.02\end{array}$ & $\begin{array}{r}8 \\
10 \\
12\end{array}$ \\
\hline $70 / 6$ & $\begin{array}{l}28 \text { July- } \\
2 \text { August }\end{array}$ & $\begin{array}{l}0.73 \\
0.45 \\
0.16\end{array}$ & $\begin{array}{l}0.27 \\
0.18 \\
0.10\end{array}$ & $\begin{array}{l}-0.50 \\
-0.35 \\
-0.21\end{array}$ & $\begin{array}{l}1.09 \\
0.64 \\
0.19\end{array}$ & $\begin{array}{l}0.17 \\
0.13 \\
0.07\end{array}$ & $\begin{array}{l}16 \\
20 \\
37\end{array}$ & $\begin{array}{l}0.75 \\
0.52 \\
0.28\end{array}$ & $\begin{array}{l}-0.04 \\
-0.05 \\
-0.07\end{array}$ & $\begin{array}{l}-0.34 \\
-0.25 \\
-0.17\end{array}$ & $\begin{array}{l}0.71 \\
0.47 \\
0.22\end{array}$ & $\begin{array}{l}0.07 \\
0.06 \\
0.05\end{array}$ & $\begin{array}{l}10 \\
13 \\
22\end{array}$ \\
\hline
\end{tabular}


vapor pressure differences over the elevation increment $\Delta z$. The convention adopted in this study is that all energy streams toward the surface are positive and all away from the surface are negative. Eq. (1) may be simplified to

$$
L E=\frac{-\left(R_{n}+S\right)}{1+\beta},
$$

where $\beta$ is the Bowen ratio and is defined as the ratio of sensible and latent heat flux $(H / L E)$.

\section{Error analysis}

The magnitude of the error in the BREB calculations of $L E$ due to errors in measurement of the constituent input parameters are estimated using the root-sumsquare error analysis technique (Scarborough, 1955). The error in $L E(\sigma L E)$ is estimated from

$$
\begin{aligned}
\sigma L E=\left\{\left[\frac{\partial L E}{\partial\left(R_{n}+S\right)} \sigma\left(R_{n}+S\right)\right]^{2}\right. \\
\left.+\left[\frac{\partial L E \sigma \Delta T}{\partial \Delta T}\right]^{2}\left[\frac{\partial L E \sigma \Delta e}{\partial \Delta e}\right]^{2}\right\}^{\frac{2}{2}} .
\end{aligned}
$$

Substitution of the partial derivatives of $L E$ with respect to the other parameters yields

$$
\begin{aligned}
\sigma L E=\left\{\left[\frac{\sigma\left(R_{n}+S\right)}{1+C \Delta T / \Delta e}\right]^{2}+\right. & {\left[\frac{\left(R_{n}+S\right) C \sigma \Delta T}{\Delta e(1+C \Delta T / \Delta e)^{2}}\right]^{2} } \\
& \left.+\left[\frac{\left(R_{n}+S\right) C \Delta T \sigma \Delta e}{(\Delta e+C \Delta T)^{2}}\right]^{2}\right\}^{\frac{1}{2}},
\end{aligned}
$$

where $C=\left(C_{p} P / L \epsilon\right)\left(K_{h} / K_{w}\right)=0.647, C_{p}=0.24 \mathrm{cal} \mathrm{gm}^{-1}$ $\left({ }^{\circ} \mathrm{C}\right)^{-1}, \quad P=973 \mathrm{mb}$ (average pressure at Mead), $L=580 \mathrm{cal} \mathrm{gm}^{-1}$ and $\epsilon=0.622$.

In estimating $\sigma L E$ the maximum expected measurement error for each parameter was used. An accuracy of $5 \%$ or $0.02 \mathrm{ly} \mathrm{min}^{-1}$ (whichever was greater) was assumed for measurement of $R_{n}+S$. A resolution of $0.013 \mathrm{C}$ was possible for measurement of $\Delta T$. An examination of data obtained with the psychrometer assemblies suggested that maximum $\Delta T$ errors should be $\sim 0.05 \mathrm{C}$. Analysis of psychrometer data indicated that maximum errors in the measurement of wet bulb temperature $\left(T_{w}\right)$ and $\Delta T_{w}$ lead to an error in $\Delta e$ of $\sim 0.10 \mathrm{mb}$.

Values of $R_{n}, \Delta T$ and $\Delta e$ were established for times of maximum, minimum and mean LE. These daily values were averaged for each study period and used to calculate $\sigma L E$ for both advective and non-advective conditions. Values of $\Delta T$ and $\Delta e$ apply to the first $25-\mathrm{cm}$ psychrometer interval above the crop canopy. Input parameters and the resultant relative errors are presented in Table 1.

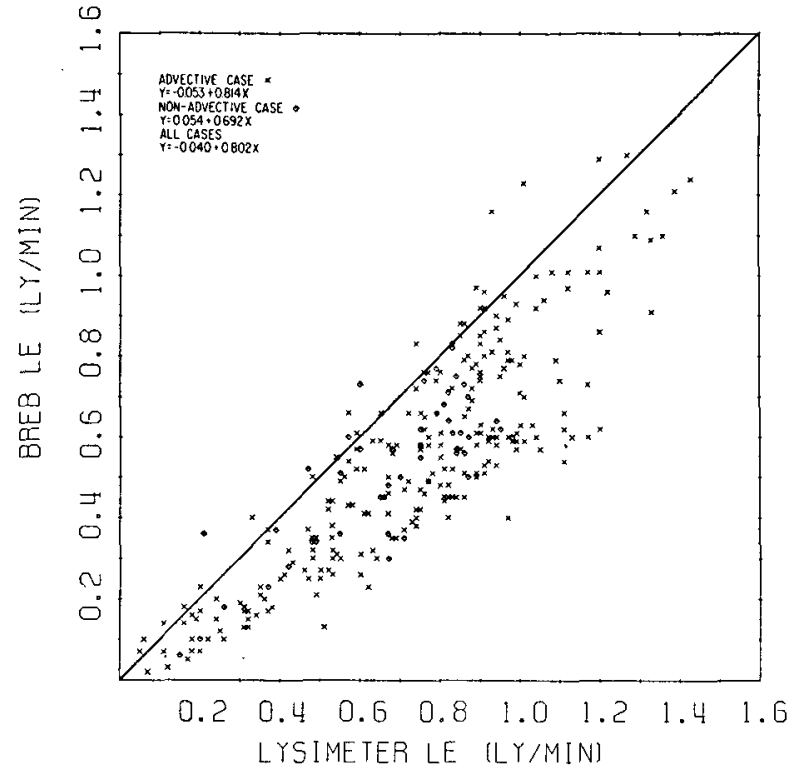

(a)

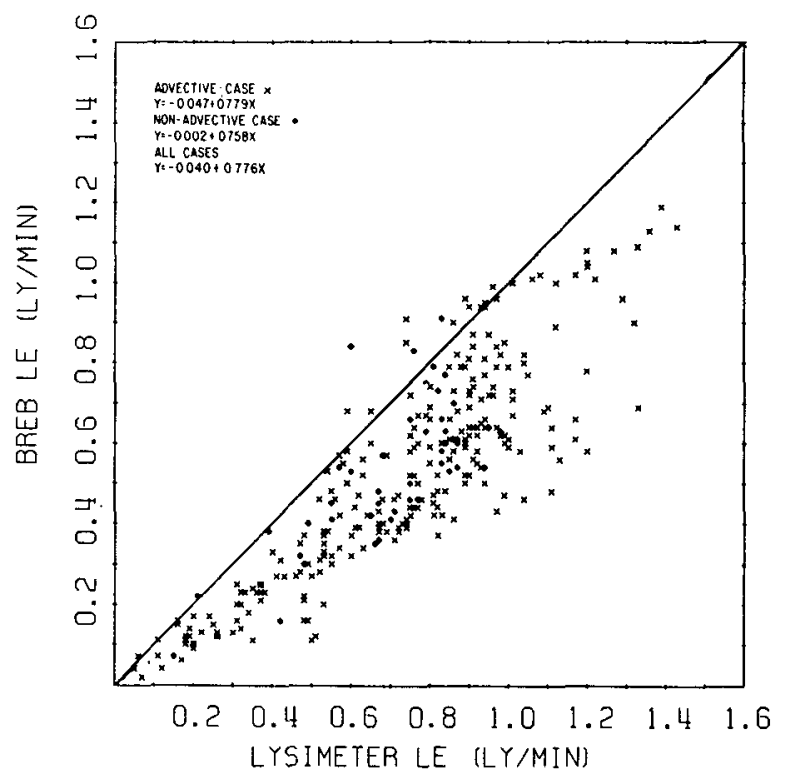

(b)

FIG. 1. Lysimetrically-measured $L E$ compared with BREBestimated $L E$ at the $75-100 \mathrm{~cm}$ level (a) and the $100-125 \mathrm{~cm}$ level (b) for 26 June-6 July, 1970 (study 70/2). Values are 30 -min means for advective conditions $(x)$ and non-advective condition $(\diamond)$.

These results show that the possible errors are greater for advective than for non-advective conditions. These errors increase as the temperature inversions become more intense because of the effect of $\Delta T$ on the denominator in (5).

The BREB method is subject to large errors when $\beta$ approaches -1 because the denominator of (2) becomes vanishingly small. This condition occurs in nature for short periods in early morning and late 


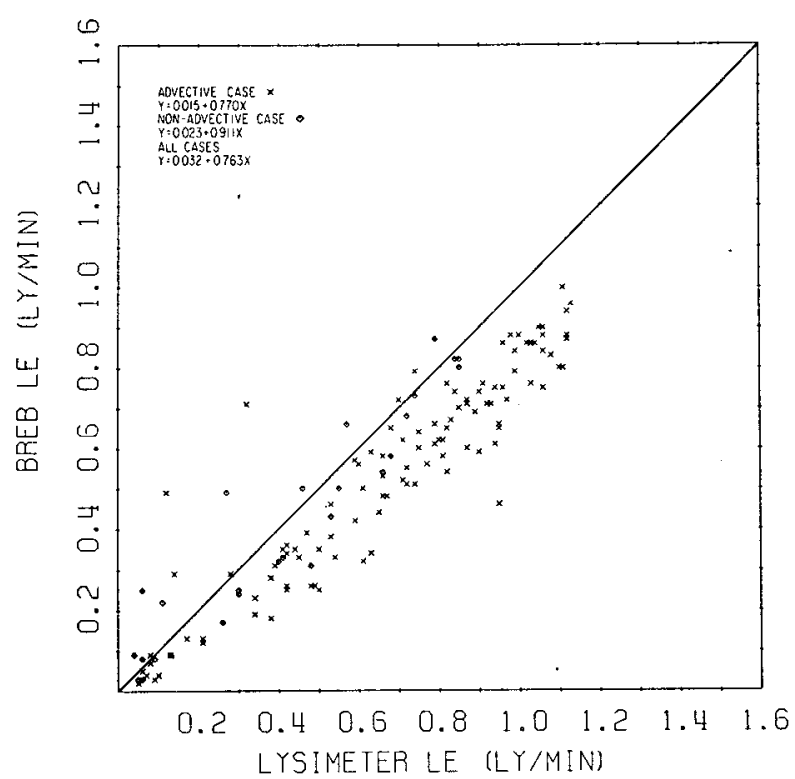

(a)

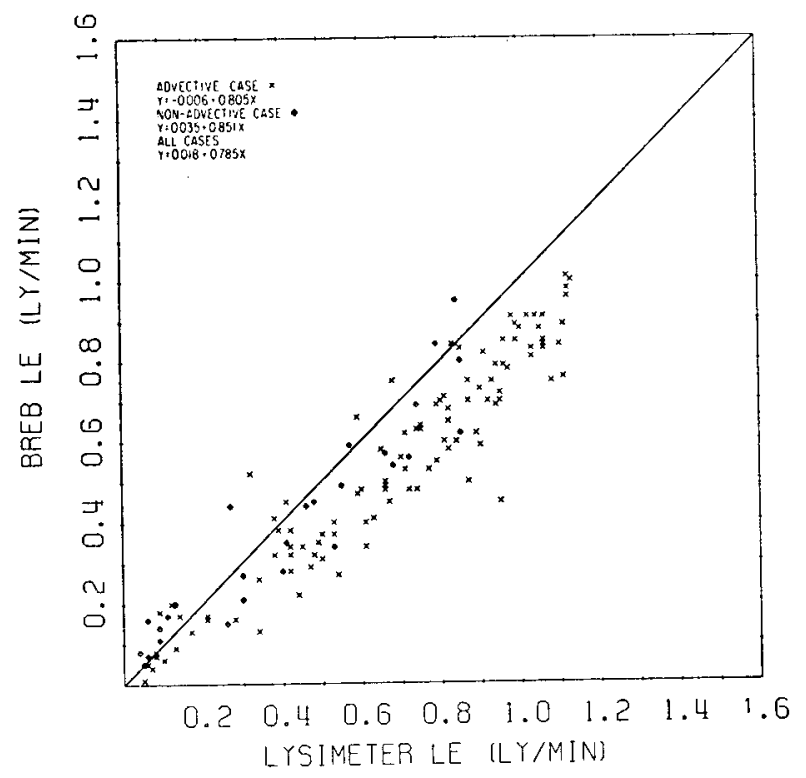

(b)

FIG. 2. As in Fig. 1 except for 6-10 July and for the intervals $100-125 \mathrm{~cm}$ (a) and $125-150 \mathrm{~cm}$ (b).

afternoon when $\left(R_{n}+S\right) \rightarrow 0$ (Fuchs and Tanner, 1970), but at such times $L E$ rates are so small as to be of little interest.

\section{Comparison of measured and calculated $L E$}

BREB-calculated ET rates using psychrometer data from the three levels nearest the crop canopy are compared to lysimeter values in Figs. 1-4. Lysimeter values are the average of two lysimeter readings. Except in the final study, the BREB estimates were made with data from only one psychrometer assembly. Only during study $70 / 6$ were the psychrometer data at each level replicated. Some of the variability observed in the plotted data is expected since BREB estimates are averages of four measurement runs during 30-min periods, whereas lysimeter values are averages based on 30-min integrations. $L E$ values during advective and non-advective periods are identified in these plots.

Linear and quadratic regressions of BREB-calculated and lysimetrically-measured $L E$ were calculated and are given in Table 2. Because of apparent differences in grouping of advective and non-advective values it was thought that a quadratic rather than a linear equation

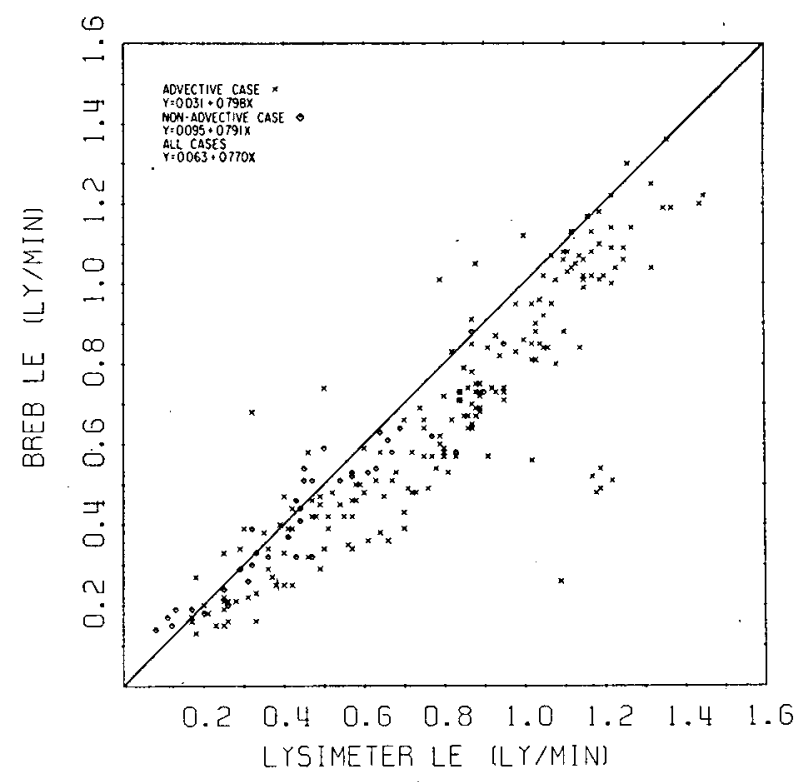

(a)

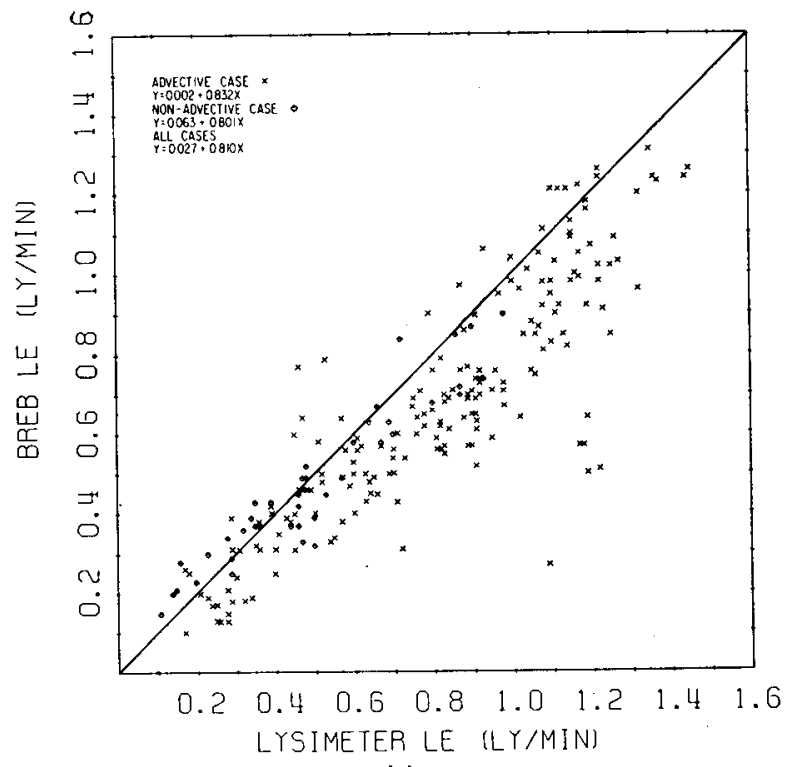

(b)

FIG. 3. As in Fig. 1 except for 14-22 July and for the intervals $125-150 \mathrm{~cm}$ (a) and $150-175 \mathrm{~cm}$ (b). 
might better fit the data. However, correlation coefficients and standard errors of estimate indicate insignificant improvement when quadratic expressions are used. Therefore, a linear equation is adequate to describe the relationship.

Data from advective and non-advective periods were separated and linear regression equations were calculated for each case. The statistical results shown in Table 3 indicate less scattering among BREB estimates of $L E$ when non-advective conditions prevailed. The results in Table 3 and Figs. 1-4 indicate some interesting trends and differences. In all four studies the BREB method underestimates $L E$ under advective conditions and nearly all values fall below the 1:1 line. Under these conditions the BREB method underestimated $L E$ by about $20 \%$. This agrees with the findings of Rosenberg (1969) and Stearns (1970).

The pattern under non-advective conditions was different. In study 70/2 almost all BREB estimates were lower than lysimeter values. During studies $70 / 3$ and $70 / 4 \mathrm{BREB}$ values were almost equally distributed on either side of the 1:1 line. During the final study the BREB model tended to overestimate. It is important to note that only a relatively small number of nonadvective cases occurred during each study. If we consider all non-advective cases for the entire growing season, reasonably good agreement results between the measured and calculated ET rates.

\section{Possible causes of BREB-method $L E$ under- estimation in advective conditions}

The observed differences between BREB-estimated and lysimetrically-measured $L E$ rates may stem from one or more of the following causes: 1) underestimation of $R_{n}$ or $S, 2$ ) underestimation of $\Delta T / \Delta z$ or overestimation of $\Delta e / \Delta z, 3)$ insufficient fetch, 4) non-equality of $K_{h}$ and $K_{w}$, and 5) overestimation of actual $L E$ by the lysimeter. These possibilities are examined below:

\section{a. Net radiation and soil heat flux}

BREB-calculated $L E$ is directly proportional to $R_{n}+S$. Therefore, if either flux is underestimated, $L E$ will be underestimated. Accurate measurement of $R_{n}$ is critical for reliable BREB estimates of $L E$, but measurement of $S$ is less critical because with complete crop cover $S$ is very small compared to $R_{n}$, except under very cloudy conditions or near sunrise and sunset.

Values of $R_{n}$ and $S$ were the average of output from two sensors each. Both sets of instruments had been recently factory calibrated and showed close agreement during the studies. Rosenberg's (1969) results at Mead, which were similar to those reported here, had been obtained using both Fritschen (1965b) and BeckmanWhitley model NI88-0I net radiometers and Beckman Whitley model ST201-1 thermal flux plates. There is no evidence to suggest that underestimation of $L E$ resulted from errors in measurement of $R_{n}+S$.

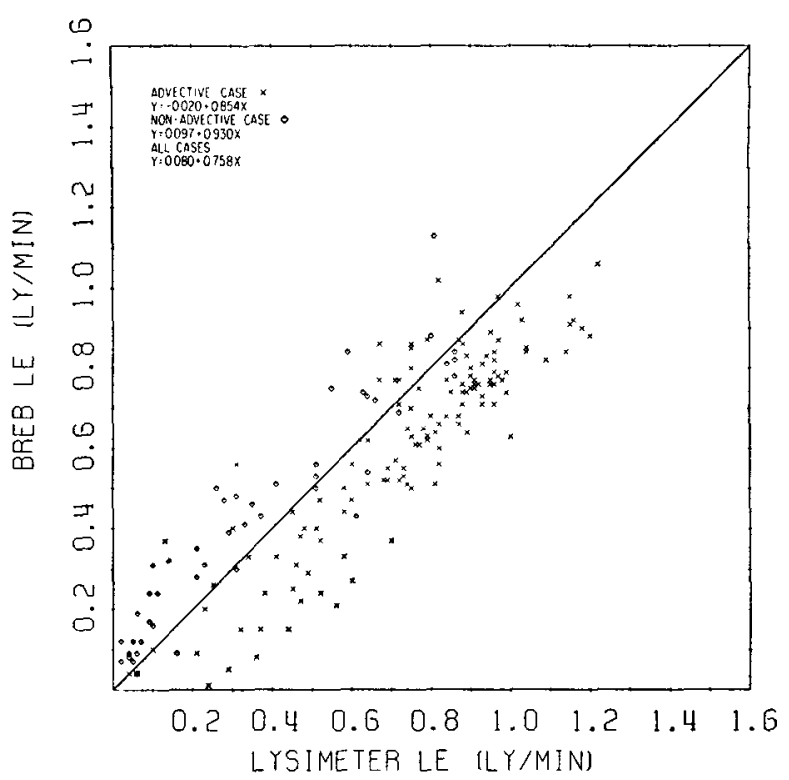

(a)

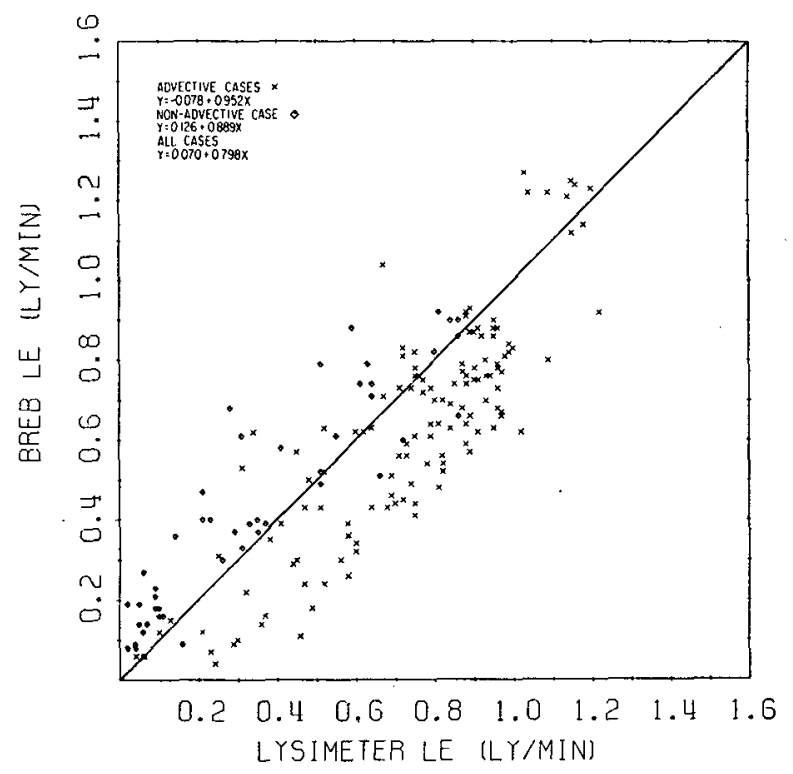

(b)

FIG. 4. As in Fig. 1 except for 28 July-2 August and for the intervals $125-150 \mathrm{~cm}$ (a) and $150-200 \mathrm{~cm}$ (b).

\section{b. Vertical temperalure and vapor pressure gradients}

A systematic underestimation of $\Delta T / \Delta z$ or overestimation of $\Delta e / \Delta z$ causes underestimation of $L E$ in advective conditions and overestimation in nonadvective conditions. Overestimation of $L E$ during non-advective conditions was not observed, suggesting that the underestimation of $L E$ under advective conditions was not due to systematic errors in measurement of temperature and vapor pressure gradients.

It is interesting to note that if all other quantities are held constant and $\Delta e / \Delta z$ is increased, then when 
TABLE 2. Regression equations of BREB-calculated $L E(Y)$ and lysimetrically-measured $L E(X)$. Units are ly min ${ }^{-1}$.

\begin{tabular}{|c|c|c|c|c|}
\hline Study & $\begin{array}{c}\text { Psychrometer } \\
\text { level }\end{array}$ & Regression equation & $\begin{array}{l}\text { Standard } \\
\text { crror of } \\
\text { estimate }\end{array}$ & $r$ \\
\hline $70 / 2$ & $\begin{array}{c}(\mathrm{cm}) \\
75-100 \\
75-100 \\
100-125 \\
100-125 \\
125-175 \\
125-175\end{array}$ & $\begin{array}{l}Y=-0.040+0.802 X \\
Y=0.000+0.660 X+0.104 X^{2} \\
Y=-0.040+0.776 X \\
Y=-0.039+0.773 X+0.002 X^{2} \\
Y=-0.002+0.744 X \\
Y=0.018+0.673 X+0.052 X^{2}\end{array}$ & $\begin{array}{l}0.134 \\
0.133 \\
0.127 \\
0.127 \\
0.173 \\
0.173\end{array}$ & $\begin{array}{l}0.864 \\
0.865 \\
0.867 \\
0.867 \\
0.775 \\
0.776\end{array}$ \\
\hline $70 / 3$ & $\begin{array}{l}100-125 \\
100-125 \\
125-150 \\
125-150 \\
150-200 \\
150-200\end{array}$ & $\begin{array}{ll}Y= & 0.032+0.763 X \\
Y= & 0.046+0.693 X+0.060 X^{\mathbf{2}} \\
Y= & 0.018+0.785 X \\
Y= & 0.049+0.629 X+0.136 X^{2} \\
Y= & 0.019+0.725 X \\
Y= & 0.039+0.623 X+0.088 X^{2}\end{array}$ & $\begin{array}{l}0.100 \\
0.100 \\
0.090 \\
0.090 \\
0.121 \\
0.121\end{array}$ & $\begin{array}{l}0.928 \\
0.928 \\
0.943 \\
0.944 \\
0.889 \\
0.889\end{array}$ \\
\hline $70 / 4$ & $\begin{array}{l}125-150 \\
125-150 \\
150-175 \\
150-175 \\
175-225 \\
175-225\end{array}$ & $\begin{array}{l}Y=0.027+0.810 X \\
Y=0.083+0.618 X+0.130 X^{2} \\
Y=0.063+0.770 X \\
Y=0.101+0.643 X+0.087 X^{2} \\
Y=0.104+0.761 X \\
Y=0.025+1.031 X-0.183 X^{2}\end{array}$ & $\begin{array}{l}0.130 \\
0.129 \\
0.133 \\
0.132 \\
0.176 \\
0.175\end{array}$ & $\begin{array}{l}0.901 \\
0.902 \\
0.888 \\
0.889 \\
0.822 \\
0.824\end{array}$ \\
\hline $70 / 6$ & $\begin{array}{l}125-150 \\
125-150 \\
150-200 \\
150-200\end{array}$ & $\begin{array}{l}Y=0.080+0.758 X \\
Y=0.071+0.806 X-0.042 X^{2} \\
Y=0.070+0.798 X \\
Y=0.135+0.459 X+0.297 X^{2}\end{array}$ & $\begin{array}{l}0.123 \\
0.123 \\
0.153 \\
0.151\end{array}$ & $\begin{array}{l}0.890 \\
0.890 \\
0.855 \\
0.861\end{array}$ \\
\hline
\end{tabular}

the BREB method is applied during advective conditions $L E$ will decrease. If such conditions actually occurred in nature the result would be increased and not decreased $L E$. It is unlikely, however, that $\Delta e / \Delta z$ would change without a concomitant change in $\Delta T / \Delta z$ or $R_{n}$.

\section{c. Fetch}

If one or more of the psychrometer levels were located above the crop boundary layer, measured temperature and vapor pressure gradients would not have been representative of the field. This situation would have arisen had downwind fetch been insufficient. It is generally agreed that fetch should be about 100 times the height of the instrument above the surface. The top psychrometer level was slightly higher than $1 \mathrm{~m}$ above the crop. Thus, $100 \mathrm{~m}$ of fetch should have been sufficient to insure that at least the lowest three psychrometer levels were within the field boundary layer. This requirement was satisfied when winds were from a southerly direction, but when winds were from the other directions the fetch was sufficient only to insure

TABLE 3. Regression equations of BREB-calculated $L E(Y)$ and lysimetrically-measured $L E(X)$ for advective and non-advective conditions. Units are ly $\mathrm{min}^{-1}$.

\begin{tabular}{|c|c|c|c|c|c|}
\hline Study & Condition & $\begin{array}{c}\text { Psychrometer } \\
\text { level }\end{array}$ & Regression equation & $\begin{array}{l}\text { Standard } \\
\text { error of } \\
\text { estimate }\end{array}$ & $r$ \\
\hline $70 / 2$ & $\begin{array}{l}\text { adv. } \\
\text { non-adv. } \\
\text { adv. } \\
\text { non-adv. }\end{array}$ & $\begin{array}{c}(\mathrm{cm}) \\
75-100 \\
75-100 \\
100-125 \\
100-125\end{array}$ & $\begin{array}{l}Y=-0.053+0.814 X \\
Y=0.054+0.692 X \\
Y=-0.047+0.779 X \\
Y=-0.002+0.758 X\end{array}$ & $\begin{array}{l}0.138 \\
0.110 \\
0.128 \\
0.120\end{array}$ & $\begin{array}{l}0.870 \\
0.793 \\
0.875 \\
0.796\end{array}$ \\
\hline $70 / 3$ & $\begin{array}{l}\text { adv. } \\
\text { non-adv. } \\
\text { adv. } \\
\text { non-adv. }\end{array}$ & $\begin{array}{l}100-125 \\
100-125 \\
125-150 \\
125-150\end{array}$ & $\begin{array}{l}Y=0.015+0.770 X \\
Y=\quad 0.023+0.911 X \\
Y=-0.006+0.805 X \\
Y=\quad 0.035+0.851 X\end{array}$ & $\begin{array}{l}0.097 \\
0.087 \\
0.088 \\
0.086\end{array}$ & $\begin{array}{l}0.926 \\
0.951 \\
0.943 \\
0.944\end{array}$ \\
\hline $70 / 4$ & $\begin{array}{l}\text { adv. } \\
\text { non-adv. } \\
\text { adv. } \\
\text { non-adv. }\end{array}$ & $\begin{array}{l}125-150 \\
125-150 \\
150-175 \\
150-175\end{array}$ & $\begin{array}{ll}Y= & 0.002+0.832 X \\
Y= & 0.063+0.801 X \\
Y= & 0.031+0.798 X \\
Y= & 0.095+0.791 X\end{array}$ & $\begin{array}{l}0.140 \\
0.060 \\
0.142 \\
0.064\end{array}$ & $\begin{array}{l}0.887 \\
0.954 \\
0.876 \\
0.947\end{array}$ \\
\hline $70 / 6$ & $\begin{array}{l}\text { adv. } \\
\text { non-adv. } \\
\text { adv. } \\
\text { non-adv. }\end{array}$ & $\begin{array}{l}125-150 \\
125-150 \\
150-200 \\
150-200\end{array}$ & $\begin{array}{l}Y=-0.020+0.854 X \\
Y=0.097+0.930 X \\
Y=-0.078+0.952 X \\
Y=0.126+0.889 X\end{array}$ & $\begin{array}{l}0.114 \\
0.094 \\
0.148 \\
0.110\end{array}$ & $\begin{array}{l}0.890 \\
0.940 \\
0.858 \\
0.915\end{array}$ \\
\hline
\end{tabular}


that the lowest two psychrometer levels were within the field boundary layer.

When irrigated fields are surrounded by dry fields, sensible heat will often be generated in the dry fields and consumed in the irrigated fields. When this occurs the horizontal and vertical temperature gradients will vary downwind from the edge of the irrigated field (Morgan et al., 1971; Hanks et al., 1971). Under these conditions Hanks et al. reported that the BREB method underestimated $L E$ by about $45 \%$.

It is unlikely that sensible heat consumed by the field in this study was generated in surrounding fields because the experimental plot was surrounded by alfalfa. Alfalfa has been shown by Rosenberg (1969) to be a strong consumer rather than a generator of sensible heat.

BREB-calculated $L E$ fluxes for the $125-150 \mathrm{~cm}$ interval were compared with the fluxes calculated at the 150-175 and the 175-225 cm layers (Figs. 5 and 6) during study $70 / 4$. There was no tendency for $L E$ fluxes at one interval to be higher than those at another level. In general, the agreement between the $L E$ fluxes calculated for each layer was very good although it was less so for fluxes calculated at the highest interval. Similar results were found during each study.

The good agreement between the $L E$ fluxes calculated at each interval is further direct evidence that measurements were made within the field boundary layer and that the contribution of local advection as a source of energy for $L E$ was negligible. The underestimation of $L E$ was not due to those factors associated with having insufficient fetch.

\section{d. Equality of exchange coefficients $K_{h}$ and $K_{w}$}

In advection conditions if the ratio $K_{h} / K_{w}$ is actually $>1$ but assumed to be unity, then the resulting BREB estimates of $L E$ will be too low. There is some indication that this ratio may be dependent upon stability conditions, i.e., by the gradient Richardson number $\mathrm{Ri}$ :

$$
\mathrm{Ri}=g \frac{\partial T}{\partial z} / T\left(\frac{\partial u}{\partial z}\right)^{2}
$$

where $g$ is the acceleration of gravity, $T$ temperature $\left({ }^{\circ} \mathrm{K}\right), u$ the wind speed, and $z$ height. Conditions are said to be stable for $\mathrm{Ri}>0$, neutral for $0 \geqslant \mathrm{Ri}>-0.035$, and unstable for $-0.035>\mathrm{Ri}$. When evaporation is occurring, then according to Crawford (1965), virtual temperature $T_{v}$ instead of $T$ should be used to calculate Ri. Eq. (6) would thus be modified to

$$
\mathrm{Ri}=g \frac{\partial T_{v}}{\partial z} / T_{v}\left(\frac{\partial u}{\partial z}\right)^{2}
$$

Pasquill (1949) found $K_{h}=K_{w}$ under stable conditions and $K_{h}>K_{w}$ with instability. At $\mathrm{Ri}=0.1$ the magnitude of $K_{h}$ was found to be twice that of $K_{w}$.

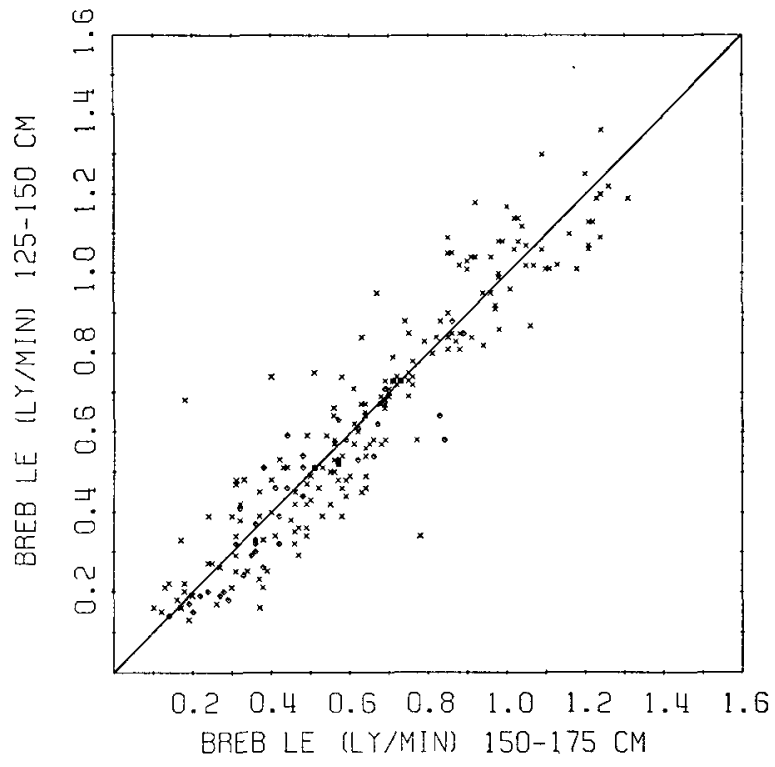

FIG. 5. BREB-calculated $L E$ for the $125-150 \mathrm{~cm}$ interval compared to $L E$ for the $150-175 \mathrm{~cm}$ interval. Data are from study 70/4, 14-22 July 1970. Values are 30-min means for advective conditions $(x)$ and non-advective conditions $(\diamond)$.

Pasquill's results, however, have been disputed by several individuals who have found serious errors in his study. Rider and Robinson (1951) reported that the ratio $K_{h} / K_{w}$ was independent of height. They assumed equality of the exchange coefficients and compared $L E$ fluxes calculated by the BREB method with those calculated using aerodynamic techniques. Except for some unexplained cases, the two methods agreed for both stable and unstable conditions; they accepted this as indirect evidence for equality of $K_{h}$

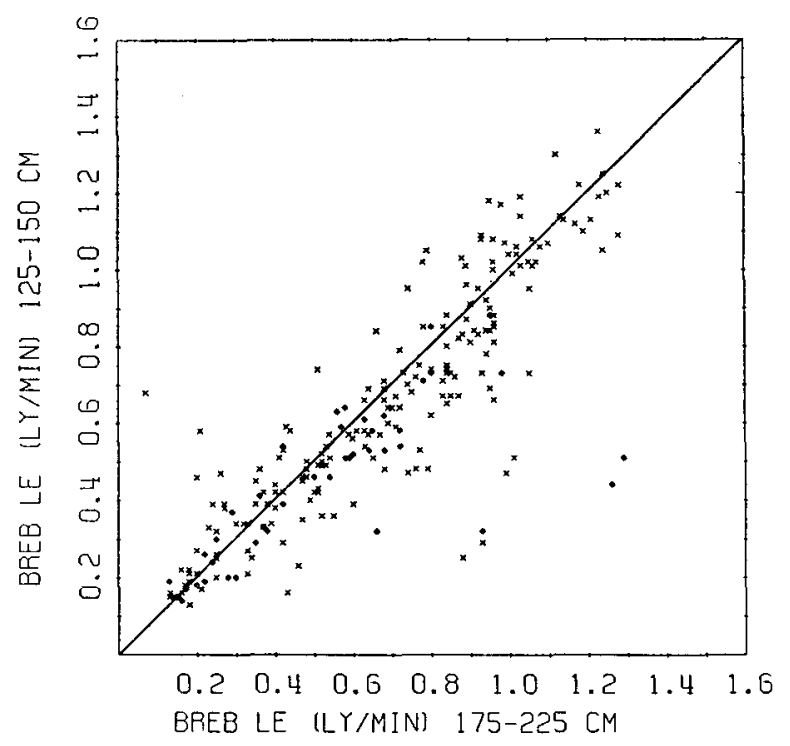

Fig. 6. As in Fig. 5 except that $L E$ for the $125-150 \mathrm{~cm}$ interval is compared to $L E$ for the $175-225 \mathrm{~cm}$ interval. 
TABLE 4. Range of Richardson numbers for 4-hr periods from 0600-1800 hours. Data are presented for two randomly selected days during each study period.

\begin{tabular}{|c|c|c|c|c|}
\hline Study & Date & Time & \multicolumn{2}{|c|}{ Richardson number for height interval } \\
\hline & & & $75-100 \mathrm{~cm}$ & $125-175 \mathrm{~cm}$ \\
\hline $70 / 2$ & $\begin{array}{l}29 \text { June } \\
\text { 1)July }\end{array}$ & $\begin{array}{l}0600-1000 \\
1000-1400 \\
1400-1800 \\
0600-1000 \\
1000-1400 \\
1400-1800\end{array}$ & $\begin{array}{ll}-0.006 \text { to } & +0.001 \\
-0.009 & -0.005 \\
-0.005 & +0.002 \\
-0.012 & +0.074 \\
+0.000 & +0.010 \\
+0.006 & +0.030\end{array}$ & $\begin{array}{ll}-0.005 \text { to } & +0.004 \\
-0.006 & -0.003 \\
-0.004 & +0.004 \\
-0.002 & +0.032 \\
+0.002 & +0.009 \\
+0.004 & +0.051\end{array}$ \\
\hline $70 / 3$ & $\begin{array}{l}7 \text { July } \\
9 \text { July }\end{array}$ & $\begin{array}{l}0600-1000 \\
1000-1400 \\
1400-1800 \\
0600-1000 \\
1000-1400 \\
1400-1800\end{array}$ & $\begin{array}{lr}-0.033 \text { to } & +0.023 \\
-0.005 & +0.007 \\
+0.001 & +0.010 \\
-0.133 & -0.020 \\
-0.150 & -0.008 \\
-0.016 & +0.023\end{array}$ & \\
\hline $70 / 4$ & 19 July & $\begin{array}{l}0600-1000 \\
1000-1400 \\
1400-1800 \\
0600-1000 \\
1000-1400 \\
1400-1800\end{array}$ & $\begin{array}{ll}+0.001 \text { to } & +0.071 \\
+0.016 & +0.041 \\
+0.043 & +0.206 \\
-0.001 & +0.001 \\
-0.001 & +0.001 \\
-0.003 & +0.001\end{array}$ & $\begin{array}{ll}+0.003 \text { to } & +0.036 \\
+0.005 & +0.017 \\
+0.011 & +0.055 \\
-0.002 & +0.008 \\
-0.001 & +0.002 \\
-0.008 & +0.002\end{array}$ \\
\hline $70 / 6$ & $\begin{array}{l}30 \text { July } \\
2 \text { August } \\
\text { : }\end{array}$ & $\begin{array}{l}0600-1000 \\
1000-1400 \\
1400-1800 \\
0600-1000 \\
1000-1400 \\
1400-1800\end{array}$ & $\begin{array}{lr}-0.009 & \text { to }+0.000 \\
-0.005 & +0.003 \\
-0.001 & +0.012 \\
-0.017 & +0.011 \\
-0.011 & -0.005 \\
+0.001 & +0.023\end{array}$ & $\begin{array}{lr}-0.008 \text { to }+0.005 \\
-0.008 & +0.002 \\
-0.000 & +0.007 \\
-0.050 & +0.084 \\
-0.006 & +0.000 \\
-0.023 & +0.051\end{array}$ \\
\hline
\end{tabular}

and $K_{w}$. Rider (1954) noted approximate equality of the exchange coefficients regardless of stability conditions in most cases but exceptions were found in which the diffusivity for heat was much larger than that for vapor.

Pruitt and Aston (1963) concluded the $K_{h} / K_{w}$ was very nearly 1.0 in unstable conditions, about $1.2-1.3$ at $\mathrm{Ri}=0$, and as high as 2-3 under very stable conditions. For unstable conditions over a freely evaporating surface Dyer (1967) and Swinbank and Dyer (1967) found that the transfer mechanisms for heat and water vapor were identical and thus that $K_{h}=K_{w}$. Denmead and McIlroy (1970) presented data supporting equality of the eddy diffusivities for heat and water vapor in the range of stability $-0.026<\mathrm{Ri}<0.001$. These studies were made on a wheat field and under conditions of non-potential evaporation.

Campbell (1973) concluded that over the stable range $0<\mathrm{Ri}<0.5$ the ratio $K_{h} / K_{w} \geqslant 1$. For the strongly stable case of $\mathrm{Ri} \approx 0.5, K_{h}$ was sufficiently greater than $K_{w}$ to lead to errors of greater than $10 \%$ in the calculation of $\beta$ and the corresponding $L E$ flux. When stability was in the range $-2.5<\mathrm{Ri}<0.025$, then $K_{h} / K_{w}$ was sufficiently close to unity to cause errors of less than $10 \%$ in estimating $\beta$.

The bulk of available evidence suggests the equality of $K_{h}$ and $K_{w}$. There is, however, support for the assertion that $K_{h} / K_{w}>1$ under stable conditions.
Richardson numbers were calculated using (7) for several levels in each of the four studies at Mead. Representative $\mathrm{Ri}$ values for 4 -hr periods from 0600 1800 for two randomly selected days from each study are given in Table 4. During these selected periods stability prevailed about $65 \%$ of the time. This is not inconsistent with the observation that advective conditions were present about $75 \%$ of the time since it is possible to have a slight temperature inversion and still have a lapse virtual temperature profile (Crawford, 1965). Thus, advection can occur during both neutral and stable conditions.

If $K_{h} / K_{w}>1$ as suggested by Pruitt and Aston (1963), Campbell (1973), and the results of this study, then the principal reason that $L E$ is underestimated in advective conditions must be an erroneous assumption of identity between $K_{h}$ and $K_{w}$.

\section{e. Lysimeter measurements of $L E$}

Slatyer and McIlroy (1961) stated that a properly designed and operated lysimeter constitutes the most direct, accurate and reliable means for determining true $L E$ from à land surface. To obtain reliable measurements of $L E$ with lysimeters it is necessary to duplicate conditions characteristic of the surrounding field. This requires some special precautions and evaluation of just how well the lysimeter represents the field is difficult. 
There are four different forms of evidence to suggest that the environment of the drop grown in the lysimeters was similar to that in the surrounding soybean field:

1) No visible differences were noted between the soybean plants growing in the lysimeters and those growing in the field.

2) There were no large or systematic differences in the soil heat flux measured in the field and in the lysimeters such as might occur when large differences in water content exist.

3) Soil moisture conditions, as determined by neutron probe measurements, were similar in both field and lysimeters. Mean water potential differences between lysimeter and field in the $15-135 \mathrm{~cm}$ layer were never greater than $\sim 0.02$ bar except on 31 July when the difference was $\sim 0.05$ bar. The 30 July observation followed three weeks of rather dry conditions although water potential in the field and lysimeters had been almost identical one week earlier.

4) Values of $\beta$ calculated from lysimeter data $\left(\beta_{\mathrm{tys}}\right)$ and those from psychrometer measurements $\left(\beta_{\mathrm{BREB}}\right)$ were calculated and plotted. As expected, the magnitudes of $\beta_{\mathrm{Lys}}$ and $\beta_{\mathrm{BREB}}$ were slightly different, but their daily patterns were in phase and both showed similar onset times for advective conditions. This evidence, although not conclusive, does suggest that ET from the lysimeters and that from the field should not have been greatly different. The two lysimeters also agreed quite well during the entire period of study. On a daily basis the agreement ranged from 0.4 to $18.6 \%$ and averaged $6.1 \%$.

\section{Summary and conclusions}

Lysimetrically-measured and BREB-estimated $L E$ were compared with data from four studies conducted during the 1970 growing season with irrigated soybeans at Mead, Nebr. Results of these studies show that the BREB method underestimates lysimetric values of ET by about $20 \%$. During the entire growing season BREB estimates and lysimetric measurements of $L E$ were in good agreement under non-advective conditions. Under advective conditions, however, the BREB method tended to underestimate $L E$ in all studies. If estimates of $L E$ by the BREB method are not corrected during advective periods ET may be underestimated in the central Great Plains by as much as $2 \mathrm{~mm}$ of water per day.

Data from this investigation suggest that the tendency of the BREB method to underestimate in advective conditions is due to an inequality of the exchange coefficients for heat and water vapor under conditions of daytime stability. No independent measurements of $K_{h}$ and $K_{w}$ were made during these studies. There is, however, evidence in the literature to support an assumption that a ratio of $K_{h} / K_{w}>1$ can exist under stable conditions. A $K_{h} / K_{w}$ ratio of $1.2-1.5$ would be sufficient to correct for the observed underestimation by the BREB method under moderately intense temperature inversions. Additional studies are required to elucidate the relationship of $K_{h}$ and $K_{w}$ under the very stable daytime conditions which occur in the east central Great Plains region during much of the growing reason.

Acknowledgments. Appreciation is expressed to Dr. Shashi Verma for many useful suggestions and to Mrs. Marilyn Beatty and Miss Sheryl Kerr for typing the manuscript. Mr. Dale Sandin and Mr. Russell Suverkrubbe assisted in making the field observations. The equipment and some of the techniques used in this study were developed under project A-017 of the Nebraska Water Resources Research Institute with support from the Office of Water Resources Research, Department of the Interior, under the Public Law 88-379 program.

\section{REFERENCES}

Brown, K. W., and N. J. Rosenberg, 1969: Computer program for plotting time dependent data with instruction and examples. Nebraska Agric. Exp. Station Misc. Publ., No. 23.

Campbell, A. P., 1973: The effect of stability on evaporation rates measured by the energy balance method. Agric. Meteor., 11, 261-267.

Crawford, T. V., 1965: Moisture transfer in free and forced convection. Quart. J. Roy. Meteor. Soc., 91, 18-27.

Denmead, O. T., and I. C. McIlroy, 1970: Measurements of nonpotential evaporation from wheat. Agric. Meteor., 7, 285-302.

Dyer, A. J., 1967: The turbulent transport of heat and water vapor in an unstable atmosphere. Quart. J. Roy. Meteor. Soc., 93, 501-508.

Fritschen, L. J., 1965a: Accuracy of evapotranspiration determination by the Bowen ratio method. Bull. Intern. Assoc. Sci. Hydrol., 10, 38-48.

- 1965b: Miniature net radiometer improvements. J. Appl. Meteor., 4, 528-532.

_-_, 1966: Evapotranspiration rates of field crops determined by the Bowen ratio method. Agron. J., 58, 339-342.

Fuchs, M., and C. B. Tanner, 1970: Error analysis of Bowen ratios measured by differential psychrometry. Agric. Meteor., 7, 329-334.

Hanks, R. J., L. H. Allen and H. R. Gardner, 1971: Advection and evapotranspiration of wide row sorghum in the central Great Plains. Agron. J., 63, 520-522.

Morgan, D. L., W. O. Pruitt and F. J. Lourence, 1971: Evapotranspiration from an irrigated turf under advection of dry air at Davis, California-A completed report. $R \& D$ Tech. Rept. ECOM 68-G10-F, Grant Da-AMC-28-043-68-G10, University of California, Davis, 53-66.

Pasquill, F., 1949: Eddy diffusion of water vapor and heat near the ground. Proc. Roy. Soc. London., A198, 116-140.

Pruitt, W. O., and M. J. Aston, 1963: Atmospheric and surface factors affecting evapotranspiration. Final Report Task 3A99-27-005-08, Contract DA-36-039-SC-80334, University of California, Davis, 69-105.

-, and F. J. Lourence, 1968: Correlation of climatological data with water requirements of crops. 1966-1968 Report, Dept. of Water Science and Engineering, University of California, Davis $59 \mathrm{pp}$.

Rider, N. E., 1954: Eddy diffusion of momentum, water vapor, and heat near the ground. Phil. Trans. Roy. Soc. London, A246, 481-501.

, and G. D. Robinson, 1951: A study of the transfer of heat 
and water vapor above a surface of short grass. Quarl. $J$. Roy. Meleor. Soc., 77, 375-401.

Rosenberg, N. J., 1969: Seasonal patterns in evapotranspiration by irrigated alfalfa in the central Great Plains. Agron. J., 61, 879-886.

— et al., 1972: Research in evapotranspiration 1969-1972 Completion Report under Project A-017, Nebraska Water Resources Res. Inst., Agreement No. 14-31-001-3527, University of Nebraska, Lincoln, Horticulture Progress Report No. 96, Chap. 6.

- , and K. W. Brown, 1970: Improvements in the van BavelMyers automatic weighing lysimeter. Water Resources Res., 6, 1227-1229.
Scarborough, J. B., 1955: Numerical Mathematical Analysis, 3rd ed. The John Hopkins University Press, $429 \mathrm{pp}$.

Slatyer, R. O., and I. C. McIlroy, 1961 : Practical Microclimatology. CSIRO, Australia, and UNESCO, Chap. 3.

Stearns, C. R., 1970: Intercomparison of flux densities of heat moisture and momentum at Davis, California, 1967. $R$ \& D Tech. Rept., Contract DAEA 18-60-C-0082 University of Wisconsin, Madison, 39-46.

Swinbank, W. C., and A. J. Dyer, 1967: An experimental study in micro-meteorology. Quart. J. Roy. Meteor. Soc., 93, 494-500.

Tanner, C. B., 1960 : Energy balance approach to evapotranspiration from crops. Soil Sci. Soc. Amer. Proc., 24, 1-9. 